Jurnal Akuakultur Sungai dan Danau Vol. 2 No. 1 Tahun 2017 Hal. 43 - 50

ISSN Online 2503-4766

\title{
METODE PENENTUAN PLOIDI PADA IKAN NILA OREOCHROMIS NILOTICUS MENGGUNAKAN KOMBINASI SEBARAN KROMOSOM DAN NUKLEOLI SECARA BERSAMAAN
}

\author{
Akhmad Taufiq Mukti \\ Departemen Manajemen Kesehatan Ikan dan Budidaya Perairan, \\ Fakultas Perikanan dan Kelautan, \\ Universitas Airlangga, Kampus C Unair, J1, Mulyorejo Surabaya 60115 \\ Korespondensi: atm_mlg@yahoo.com
}

\begin{abstract}
Ploidy determination in fish was need the accurate, simple and rapid method. This research was aimed to develop ploidy determination method in Nile tilapia use combination of chromosome and nucleoli spreads simultaneously. Ten fish of 30-day-old Nile tilapias were used in this research. Solid tissues for preparation were collected on the caudal fin of the fish. The result showed that chromosome and nucleoli spreads simultaneously were easily observed in same preparate. Ploidy determination in Nile tilapia can done very accurate and fast use combination of chromosome and nucleoli spreads simultaneously as indicators to ploidy level determination in fish.

Keywords: chromosome spread, nucleoli spread, simultaneously, ploidy level, tilapia
\end{abstract}

\begin{abstract}
Abstrak
Penentuan ploidi pada ikan diperlukan metode yang akurat, mudah dan cepat. Tujuan penelitian ini adalah mengembangkan metode penentuan ploidi pada ikan nila menggunakan kombinasi sebaran kromosom dan nukleoli secara bersamaan. Sebanyak sepuluh ekor ikan nila umur 30 hari digunakan dalam penelitian ini. Jaringan padat untuk preparasi dikoleksi untuk preparasi adalah sirip ekor ikan. Hasil penelitian menunjukkan bahwa sebaran kromosom dan nukleoli secara bersamaan mudah diamati pada preparat yang sama. Penentuan ploidi pada ikan nila dapat dilakukan secara lebih akurat dan cepat menggunakan kombinasi sebaran kromosom dan nukleoli secara bersamaan sebagai indikator penentu tingkat ploidi pada ikan.

Kata kunci: sebaran kromosom, sebaran nukleoli, secara bersamaan, penentuan ploidi, ikan nila
\end{abstract}

\section{PENDAHULUAN}

Metode identifikasi pengujian tingkat ploidi tergantung pada peralatan, pengalaman staf laboratorium atau farm, dan studi materialnya, seperti spesies ikan, umur, dan ukuran spesimen. Kombinasi beberapa teknik mudah dapat sangat membantu lebih cepat, dipercaya, dan penduga pengaruh manipulasi genom (Jankun et al. 2007). Pada beberapa penelitian, metode mudah dan cepat untuk verifikasi tingkat ploidi diperlukan. Perlakuan poliploidisasi tidak selalu berhasil 100\% dan kemungkinan masih campuran (mosaic), sehingga diperlukan metode penentuan ploidi yang akurat. Beberapa metode penentuan ploidi, antara lain: menghitung jumlah kromosom, menghitung jumlah nukleoli atau nucleolar organizer regions (NORs), menguji ukuran sel dan jumlah sel, menguji ukuran sel eritrosit dan ukuran inti sel eritrosit, analisis densitas sel, penentuan komponen atau kandungan DNA pada nukleus eritrosit menggunakan flow cytometry dan mikrosatelit (Bai et al. 2011). Flow cytometry, spectrofluorometry atau microdensitometry adalah teknik 
Jurnal Akuakultur Sungai dan Danau Vol. 2 No. 1 Tahun 2017 Hal. 43 - 50

ISSN Online 2503-4766

yang mudah dan cepat untuk validasi jumlah DNA (Hardie et al. 2002), tetapi biaya dan peralatan yang diperlukan sangat mahal, termasuk juga mikrosatelit. Parameter sitologi lain yang dapat digunakan dalam penentuan tingkat ploidi, seperti Wlasow et al. (2004) yang menjabarkan "ploidy specific pattern" dari nukleoli eritrosit dan granulosit pada ikan brook trout maupun analisis dimensi eritrosit, seperti pada ikan brook trout (Woznicki \& Kuzminski 2002).

Penghitungan jumlah kromosom adalah satu metode yang memungkinkan penentuan secara langsung tingkat ploidi, karena jumlah kromosom mengindikasikan jumlah molekul DNA. Preparasi kromosom dapat dibuat dari head kidney, epithelium insang, seluruh tubuh ikan, atau dari kultur sel darah (Ozouf-Costaz \& Foresti 1992). Struktur dasar kromosom dapat diamati di bawah mikroskop cahaya (Schreck \& Moyle 1990). Keberhasilan preparasi kromosom secara umum hingga saat ini masih mengandalkan bahan penghambat metafase, seperti kolkisin dan atau kolsemid, sehingga ketergantungan terhadap bahan kimia tersebut sangat tinggi.

Metode pewarnaan perat nitrat telah dikembangkan oleh Howell dan Black (1980). Metode pewarnaan perak nitrat untuk menghitung nukleoli (NORs) telah diaplikasikan untuk verifikasi ploidi Abramis brama dan Esox lucius (Kucharczyk et al. 1999), rainbow trout (Babiak et al. 1998), brook trout (Phillips \& Ihssen 1985), common carp (Carman et al. 1992; Carman 1992; Mukti et al. 2001; Mukti 2005, Mukti \& Mubarak 2007), dan nila merah (Carman et al. 1997). Metode ini tidak bermanfaat pada sturgeon (termasuk Huso huso) karena sistem yang multi dari NORs (Fontana 2002).

Beberapa peneliti juga telah menentukan tingkat ploidi pada ikan menggunakan kombinasi indikator penentu tingkat ploidi, seperti jumlah kromosom dan ukuran inti eritrosit (Pradeep et al. 2011a), jumlah nukleoli dan ukuran inti eritrosit (Jankun et al. 2007), jumlah kromosom dan ukuran inti eritrosit (Woznicki \& Kuzminski 2002; Dorota et al. 2006), serta jumlah kromosom dan jumlah nukleoli (Uma dan Chandran 2008). Akan tetapi, kombinasi-kombinasi tersebut dilakukan melalui metode preparasi yang berbeda dan umumnya menggunakan spesimen yang berbeda, sehingga dirasa kurang efisien dan efektif. Berdasarkan kenyataan tersebut, perlu dikembangkan metode identifikasi ploidi pada ikan yang lebih mudah, cepat dan murah menggunakan indikator penentu tingkat ploidi secara bersamaan. Tujuan penelitian ini adalah mengembangkan metode penentuan ploidi pada ikan nila menggunakan kombinasi sebaran kromosom dan nukleoli secara bersamaan.

\section{Materi dan Metode}

Ikan nila yang digunakan dalam penelitian ini adalah ikan nila strain Wanayasa (NIRWANA). Perkawinan induk ikan nila dilakukan secara alami dan terkontrol dalam akuarium dengan volume $100 \mathrm{~L}$, sedangkan pemijahan dan fertilisasi telur dilakukan secara buatan. Inkubasi dan penetasan telur dilakukan secara terkontrol menggunakan sistem resirkulasi air tertutup dengan volume wadah penetasan sekitar $350 \mathrm{~mL}$ dengan suhu air inkubasi terkontrol sekitar $29-30^{\circ} \mathrm{C}$. Ikan nila triploid diproduksi melalui perlakuan kejut suhu $41^{\circ} \mathrm{C}$ selama empat menit embrio umur empat menit setelah fertilisasi berdasarkan Mukti (2016), Mukti et al. (2016a, b, c). 
Setelah telur menetas, larva ikan dipelihara dalam akuarium volume $50 \mathrm{~L}$ dan ikan diberi pakan alami Moina sp. dan Tubifex sp. secara bertahap. Selanjutnya, benih ikan diberi pakan buatan pellet halus dengan kandungan protein sekitar 33\% dan pakan buatan pellet kecil dengan kandungan protein sekitar $40 \%$ secara bertahap. Saat ikan berumur 30 hari, sebanyak sepuluh ekor ikan diambil sebagai sampel untuk preparasi.

Preparasi menggunakan jaringan padat kombinasi metode Kligerman dan Bloom (1977) yang dimodifikasi tanpa perlakuan bahan kimia penghambat metafase dengan pewarnaan perak nitrat metode Howell dan Black (1980), sedangkan jaringan padat yang digunakan untuk preparasi adalah potongan sirip ekor sebagaimana Mukti (2016) dan Mukti et al. (2016). Sebaran sel diamati di bawah mikroskop untuk mengamati dan menghitung sebaran kromosom dan nukleoli. Sebaran kromosom dan nukleoli dihitung dari seratus sel yang diamati, sedangkan sebaran metafase kromosom yang baik dihitung maksimal dari 20 sel yang ditemukan berdasarkan penelitian Pradeep et al. (2011b). Mikroskop yang digunakan untuk mengamati preparat adalah mikroskop Olympus BH2RFCA yang dilengkapi dengan kamera Canon. Pembesaran yang digunakan 400-1000 kali tanpa minyak imersi.

Sebaran kromosom dan nukleoli yang baik difoto dan didokumentasikan. Selanjutnya, data dianalisis secara deskriptif.

\section{Hasil}

Berdasarkan hasil penelitian ini, sebaran kromosom dan nukleoli dapat terlihat secara bersamaan dalam satu lapang pandang pada preparat yang sama, seperti terlihat pada Gambar 1. Sebaran kromosom ikan nila diploid berkisar antara 29-50 sel (29-50\%) dengan rerata $39.1 \pm 2.88 \%$, sedangkan ikan nila triploid berkisar antara 20-27 sel (20-27\%) dengan rerata $23.29 \pm 2.63 \%$ (Tabel 1). Akan tetapi berdasarkan sebaran metafase kromosom yang baik, ikan nila diploid dan triploid, masing-masing sekitar 85-100\% dengan rerata $97 \pm 4.83 \%$ dan sekitar $70-90 \%$ dengan rerata $81.43 \pm 8.52 \%$ (Tabel 2).

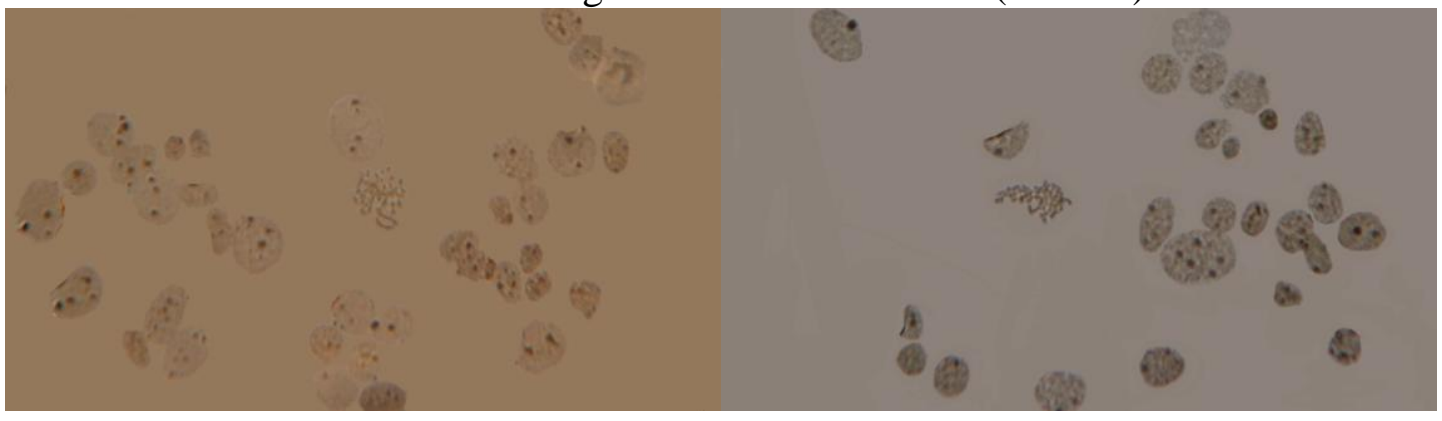

Gambar 1. Sebaran kromosom dan nuk!eoli ikan nila secara bersamaan; diploid (a) dan triploid (b) dalam satu preparat pada pembesaran $400 \mathrm{x}$ 
Jurnal Akuakultur Sungai dan Danau Vol. 2 No. 1 Tahun 2017 Hal. 43 - 50

ISSN Online 2503-4766

\begin{tabular}{cccc}
\hline \hline \multicolumn{2}{c}{ Tabel } & \multicolumn{3}{c}{ Sebaran kromosom ikan nila diploid dan triploid hasil preparasi } \\
\cline { 3 - 4 } Ikan & Jumlah Sel & \multicolumn{2}{c}{ Sebaran Kromosom (sel) } \\
\hline 1 & (sel) & Diploid & Triploid \\
\hline 2 & 100 & 40 & 20 \\
3 & 100 & 35 & 23 \\
4 & 100 & 37 & 23 \\
5 & 100 & 42 & 25 \\
6 & 100 & 42 & 20 \\
7 & 100 & 40 & 25 \\
8 & 100 & 42 & 27 \\
9 & 100 & 40 & - \\
10 & 100 & 34 & - \\
\hline
\end{tabular}

Tabel 2. Sebaran metafase kromosom ikan nila diploid dan triploid yang baik

\begin{tabular}{|c|c|c|c|c|}
\hline \multirow{3}{*}{ Ikan } & \multicolumn{4}{|c|}{ Sebaran Metafase Kromosom (sel) } \\
\hline & \multicolumn{2}{|c|}{ Diploid } & \multicolumn{2}{|c|}{ Triploid } \\
\hline & (sel) & (\%) & (sel) & $(\%)$ \\
\hline 1 & 20 & 100 & 16 & 80 \\
\hline 2 & 20 & 100 & 17 & 85 \\
\hline 3 & 19 & 95 & 14 & 70 \\
\hline 4 & 19 & 95 & 17 & 85 \\
\hline 5 & 20 & 100 & 14 & 70 \\
\hline 6 & 20 & 100 & 18 & 90 \\
\hline 7 & 20 & 100 & 18 & 90 \\
\hline 8 & 20 & 100 & - & - \\
\hline 9 & 17 & 85 & - & - \\
\hline 10 & 19 & 95 & - & - \\
\hline
\end{tabular}

Keterangan : Jumlah dan persentase sebaran metafase kromosom yang baik berdasarkan penelitian Pradeep et al. (2011b), yaitu 20 sel (100\%)

Berdasarkan sebaran nukleoli, ikan nila diploid dan triploid memiliki variasi jumlah nukleoli dalam inti selnya. Ikan nila diploid memilki jumlah nukleoli 1, 2, 3, dan 4 (maksimal), sedangkan ikan nila triploid memiliki jumlah nukleoli 1, 2, 3, 4, 5, dan 6 (maksimal), masing-masing juga memiliki variasi jumlah nukleoli yang berbeda (Tabel 3).

Tabel 3. Sebaran dan variasi nukleoli ikan nila diploid dan triploid hasil preparasi

\begin{tabular}{lcccccccccc}
\hline \multirow{2}{*}{ Ikan } & Jumlah & \multirow{2}{*}{ Ikan } & \multirow{2}{*}{ Jumlah Sel / Ikan } & \multicolumn{4}{c}{ Jumlah Nukleoli / Sel / Ikan } & \multirow{2}{*}{ Total Sel } \\
\cline { 4 - 9 } & (ekor) & $($ sel) & 1 & 2 & 3 & 4 & 5 & 6 & 7 & (sel) \\
\hline Diploid & 10 & 100 & 29 & 40 & 11 & 20 & - & - & - & 1000 \\
Triploid & 10 & 100 & 4 & 11 & 30 & 18 & 25 & 12 & - & 1000 \\
\hline
\end{tabular}


Jurnal Akuakultur Sungai dan Danau Vol. 2 No. 1 Tahun 2017 Hal. 43 - 50

ISSN Online 2503-4766

\section{Pembahasan}

Jumlah kromosom ikan nila diploid adalah 44 atau 22 pasang, walaupun ditemukan pula beberapa yang terhitung 40-42 atau 20-21 pasang, termasuk dua $G C$, sedangkan ikan nila triploid memiliki kromosom sejumlah 66 atau 33 pasang dengan tiga $G C$. Ikan nila telah diteliti oleh beberapa peneliti memiliki jumlah kromosom $2 n=44$ dan $3 n=66$ (Hussain 1995; Pradeep et al. 2011a,b; Mukti et al. 2016b,c). Ikan nila yang memiliki 15 jenis dari tiga genus utama, yaitu Oreochromis, Sarotherodon, dan Tilapia telah diteliti dan beberapa spesies memiliki kariotip yang sama, 22 pasang kromosom termasuk satu pasang kromosom besar (Harvey et al. 2002a). Ada empat pengecualian, yaitu Tilapia mariae dengan $2 \mathrm{n}=40$ (Ferreira et al. 2010), Tilapia sparrmanii dengan 2n=42 (Thompson 1981), Oreochromis alcalicus dengan 2n=48 (Park 1974), dan Oreochromis karongae dengan 2n=38 (Harvey et al. 2002b). Jumlah kromosom ikan nila hasil preparasi yang terhitung kurang dari 44, kemungkinan besar akibat terjadinya penumpukan dan atau terpisah dari kumpulan kromosomnya. Hal ini dimungkinkan terjadi diakibatkan proses penyebaran sel ke slide yang kurang sempurna, baik karena suhu hot plate terlalu dingin atau panas, terlalu keras droping, larutan suspensi sel saat chopping terlalu banyak (encer), dan atau perlakuan hipotonik yang kurang tepat.

Pembuatan slide adalah aspek kritis preparasi kromosom. Variabel yang mempengaruhi preparasi termasuk kelembaban, suhu ruang, waktu pengeringanginan, dan jumlah sel per slide. Hal ini juga terlihat dari hasil penelitian, bahwa sebaran kromosom yang diperoleh masih rendah sekitar 40\% untuk diploid dan 20-30\% untuk triploid (dari 100 sel yang dihitung, Tabel 1). Akan tetapi, sebaran metafase kromosom yang baik dapat mencapai 100\% (75-100) untuk ikan nila diploid dan 70-90\% untuk ikan nila triploid. Pada ikan nila, persentase sebaran metafase kromosom ini kemungkinan tidak terlalu signifikan untuk penentuan tingkat ploidi ikan, karena keuntungan dari kromosom ikan nila adalah memiliki kromosom penanda $(G C)$ yang secara umum dapat dijadikan sebagai indikator tingkat ploidi ikan dengan menghitung jumlah $G C$, yaitu $1 \mathrm{n}=1 G C, 2 \mathrm{n}=2 G C, 3 \mathrm{n}=3 G C$, dan $4 \mathrm{n}$ $=4 G C$.

Pradeep et al. (2011b) menjelaskan, setiap tahapan preparasi kromosom, mulai preparasi jaringan, penyebaran sel pada slide, hingga akhir proses preparasi (pewarnaan) merupakan faktor penting yang kritis pada keberhasilan preparasi kromosom, terutama mendapatkan sebaran metafase kromosom yang baik dan banyak. Sebaran kromosom yang baik juga dapat dipengaruhi oleh faktor perlakuan hipotonik. Foresti et al. (1992) menemukan bahwa selain perlakuan prefiksatif, volume larutan hipotonik mempengaruhi keberhasilan mendapatkan sebaran kromosom yang baik saat preparasi kromosom ikan Silurus glanis (Siluridae) dan Scardinus erythropththalmus (Cyprinidae).

Pada penelitian ini, jaringan sirip ekor yang digunakan menunjukkan hasil yang relatif bagus terhadap sebaran kromosom dan nukleoli. Jaringan atau organ yang digunakan dalam preparasi kromosom mempengaruhi keberhasilan mendapatkan sel mitotik tinggi, sehingga diharapkan sebaran metafase kromosom banyak didapat. Jaringan yang dapat tumbuh cepat memiliki sel mitotik tinggi, sehingga memungkinkan sebaran metafase kromosom yang diperoleh dalam preparasi kromosom juga tinggi, walaupun hal ini masih dipengaruhi oleh tahapan preparasi kromosom yang lainnya. Jaringan sirip ikan nila memiliki indeks mitotik tinggi sebagaimana penelitian Mukti (2016) dan Mukti et al. (2016b). Sirip dan insang ikan 
Jurnal Akuakultur Sungai dan Danau Vol. 2 No. 1 Tahun 2017 Hal. 43 - 50

ISSN Online 2503-4766

termasuk jaringan yang cepat tumbuh. Pradeep et al. (2011b) menyatakan bahwa efektivitas preparasi kromosom hanya dapat dihasilkan dengan jumlah populasi sel dari jaringan yang memiliki sel mitotik tinggi. Tan et al. (2004) menyatakan bahwa jaringan yang tumbuh sangat cepat diperlukan untuk mendapatkan jumlah besar sebaran kromosom pada metafase untuk studi kariologi.

Berdasarkan sebaran nukleoli, ikan nila diploid memiliki variasi jumlah nukleoli 1, 2, 3, dan maksimal 4, sedangkan ikan nila triploid memiliki variasi jumlah nukleoli 1, 2, 3, 4, 5, dan maksimal 6. Variasi jumlah dan persentase nukleoli per sel juga berbeda, baik diploid maupun triploid (Tabel 3). Carman et al. (1992) menjelaskan bahwa variasi yang terjadi pada jumlah maksimum nukleoli kemungkinan disebabkan fusi dan fisi dari bentuk nukleoli tunggal atau tiga, karena beberapa proses fisiologis yang terjadi selama siklus sel. Variasi ini adalah merupakan faktor sulit pada interpretasi level ploidi pada pengamatan individu-individu yang dipergunakan. Variasi jumlah maksimum nukleoli per sel pada individu diploid dan triploid berhubungan dengan umurnya. Phillips et al. (1986) mengatakan bahwa peningkatan jumlah nukleoli pada ikan triploid disebabkan karena adanya penambahan sejumlah nukleoli yang berasal dari polar body II dan berhasil bergabung dengan pronukleus betina dan pronukleus jantan akibat adanya kejutan panas yang dilakukan. Peningkatan jumlah nukleoli merupakan indikasi peningkatan jumlah kromosom pada ikan triploid.

Penentuan ploidi pada ikan nila dapat dilakukan melalui pengamatan jumlah kromosom dan jumlah nukleoli secara bersamaan sebagai indikator kuat penentu tingkat ploidi pada ikan. Hasil penelitian ini memungkinkan dikembangkan untuk preparasi yang menghasilkan gambaran sebaran kromosom dan nukleoli secara bersamaan pada spesies ikan yang lain menggunakan jaringan yang mudah dikoleksi tanpa menyebabkan kematian ikan serta lebih mudah, cepat, dan murah.

\section{Simpulan}

Metode penentuan ploidi pada ikan nila dapat dilakukan menggunakan kombinasi sebaran kromosom dan nukleoli secara bersamaan. Preparasi tanpa perlakuan bahan penghambat metafase seperti kolkisin dan kolsemid dengan pewarnaan perak nitrat dapat menghasilkan sebaran kromosom dan nukleoli secara bersamaan sebagai indikator kuat penentu tingkat ploidi pada ikan nila.

\section{Ucapan Terima Kasih}

Penulis haturkan terima kasih kepada Kementerian Riset, Teknologi dan Pendidikan Tinggi atas sponsor BPP-DN dan Lembaga Pengelola Dana Pendidikan (LPDP) Kementerian Keuangan atas Beasiswa Disertasi, Drs. Odang Carman dan Alimuddin serta Profs. Muhammad Zairin Junior dan Komar Sumantadinata (alm.) atas arahan, bimbingan dan ilmunya serta Kepala dan Staf Balai Pengembangan Budidaya Ikan Nila dan Mas Wanayasa, Purwakarta, Jawa Barat atas bantuan penyediaan induk ikan NIRWANA. 
Jurnal Akuakultur Sungai dan Danau Vol. 2 No. 1 Tahun 2017 Hal. 43 - 50

ISSN Online 2503-4766

\section{Daftar Pustaka}

Babiak I, Dobosz S, Goryczko K, Kuzminski H, Woznicki P. 1998. Androgenesis in Rainbow Trout, Oncorhynchus mykiss, Using Gamma Irradiation and Heat Shock. Aquaculture Europe '98. Aquaculture and Water: Fish Culture, Shellfish Culture and Water Usage. Bordeaux, France. October 7-10, 1998.

Bai Z, Liu F, Li J, Yue GH. 2011. Identification of triploid individuals and clonal lines in Carassius auratus complex using microsatellites. Int. J. Biol. Sci. 7: 279-285.

Carman O, Alimuddin, Sastrawibawa S, Arfah H. 1997. Determinasi kromosom dan nukleoli kelamin pada ikan nila merah (Oreochromis sp.). Zuriat 8(2):83-89.

Carman O., Oshiro T, Takashima F. 1992. Variation in the maximum number of nucleoli in diploid and triploid common carp. Nippon Suisan Gakkaishi 58(12):2303-2309.

Dorota F-B, Jankun M, Woznicki P. 2006. Chromosome number and erythrocyte nuclei length in triploid Siberian sturgeon Acipenser baeri Brandt. Caryologia 59(4): 319-321.

Ferreira IA, Poletto AB, Mota-Velasco J, Penman DJ, Kocher TD, Martins C. 2010. Chromosome evolution in African Cichlid fish: Contributions from the physical mapping of repeated DNAs. Cytogenetics and Genome Research (in press).

Fontana F. 2002. A cytogenetic approach to the study of taxonomy and evolution in sturgeons. J. Appl. Ichthyol. 18:226-233.

Foresti F, Ozouf-Costaz C, Rab P. 1992. Volume dependent effect of hypotonic treatment on good spreading of fish chromosomes. Cybium 16(3):209-212.

Hardie DC, Gregory TR, Hebert PDN. 2002. From pixels to picograms: A beginners' guide to genome quantification by Feulgen image analysis densitometry. J. Histochem. Cytochem. 50:735-749.

Harvey SC, Campos-Ramos R, Kennedy RR. 2002a. Karyotype evolution in Tilapia: Mitotic and meiotic chromosome analysis of Oreochromis karongae and O. niloticus $\times$ O. karongae hybrids. Genetica 115:169-177.

Harvey SC, Powell SF, Kennedy DD, McAndrew BJ, Penman DJ. 2002b. Karyotype analysis of Oreochromis mortimeri (Trewavas) and Sarotherodon melanotheron (Rüppell). Aqua. Res. 33:339-342.

Howell WM, Black DA. 1980. Controlled silver staining of nucleolus organizer regions with a protective colloidal developer: A 1-step method. Experientia 36:1014-1015.

Hussain MG. 1995. Suppression of meiotic and mitotic cell divisions in Nile tilapia, Oreochromis niloticus L., and induction of triploids two types of gynogenetic diploids. Asian Fish. Sci. 8:133-142.

Jankun M, Kuzminski H, Furgala-Selezniow G. 2007. Cytologic ploidy determination in fish - an example of two salmonid species. Environ. Biotechnol. 3(2):52-56.

Klingerman AD, Bloom SE. 1977. Rapid chromosome preparation from solid tissues of fish. J. Fish. Res. Bd Can. 34:266-269.

Kucharczyk D, Woznicki P, Luczynski MJ, Klinger M, Luczynski M. 1999. Ploidy level determination in genetically manipulated northern pike based on the number of active nucleoli per cell. North Am. J. Aqua. 61:38-42.

Mukti AT. 2005. Perbedaan keberhasilan tingkat poliploidisasi ikan mas (Cyprinus carpio Linn.) melalui kejutan panas. Berkala Penel. Hayati 10(2):133-138. 
Jurnal Akuakultur Sungai dan Danau Vol. 2 No. 1 Tahun 2017 Hal. 43 - 50

ISSN Online 2503-4766

Mukti AT. 2016. Triploidi dan Dimorfisme Seks, Performa Reproduksi dan Produksinya pada Ikan Nila Oreochromis niloticus. Disertasi. Sekolah Pascasarjana, Institut Pertanian Bogor. Bogor. 100 hal.

Mukti AT, Carman O, Alimuddin, Zairin Jr. M. 2016b. A rapid chromosome preparation technique without metaphase arrest for ploidy determination in Nile tilapia, Oreochromis niloticus. Caryologia 69(2):175-180.

Mukti AT, Carman O, Alimuddin, Zairin Jr. M. 2016c. Triploidy Success of Nile Tilapia Oreochromis niloticus Strain Wanayasa by Heat Shock and Zygote Age Treatments. First International Conference on Aquaculture Biotechnology (ICAB) Bogor, 12 Oktober 2016.

Mukti AT, Mubarak AS. 2007. Identifikasi Variasi Nukleoli pada Ikan Mas (Cyprinus carpio) Dengan Tingkat Ploidi Berbeda. Prosiding Seminar Nasional Breeding, Genetika dan Bioteknologi Perikanan, Nov 12, 2007. Bali, Indonesia. pp. 80-83.

Mukti AT, Rustidja, Sumitro SB, Djati MS. 2001. Poliploidisasi ikan mas (Cyprinus carpio L.). J. Ilmu-Ilmu Hayati BIOSAIN 1(1):111-123.

Ozouf-Costaz C, Foresti F. 1992. Fish cytogenetic research: Advances, applications, and perspectives. Netherland J. Zool. 42:277-290.

Park EH. 1974. A list of the chromosome numbers of fishes. Coll. Rev. Lib. Arts Sci. Seoul Nat. Univ. 20:346-372.

Phillips RB, Ihssen PE. 1985. Chromosome banding in salmonid fish: Nucleolar organizer regions in Salmo and Salvelinus. Can. J. Gen. Cytol. 27:433-440.

Phillips RB, Zajicek KD, Ihssen PE, Johnson O. 1986. Application of silver staining to the identification of triploid fish cells. Aquaculture 54:313-319.

Pradeep PJ, Srijaya TC, Jose D, Papini A, Hassan A, Chatterji AK. 2011a. Identification of diploid and triploid red tilapia by using erythrocyte indices. Caryologia 64(4):485-492.

Pradeep PJ, Srijaya TC, Zain RBM, Papini A, Chatterji AK. 2011b. A simple technique for chromosome preparation from embryonic tissues of teleosts for ploidy verification. Caryologia 64(2):235-241.

Schreck CB, Moyle PB. 1990. Methods for Fish Biology. American Fisheries Society, Maryland, USA. 553 p.

Tan X, Qin JG, Chen B, Chen L, Li X. 2004. Karyological analysis on red claw crayfish Cherax quadricarinatus (Decapoda: Parastacidae). Aquaculture 234:65-76.

Thompson KW. 1981. Karyotypes of six species of African Cichlidae (Pisces: Perciformes). Experientia 37:351-352.

Uma B, Chandran MR. 2008. Induction of triploidy in Gymnocorymbus ternetzi (Boulenger). Res. J. Fish. Hydrobiol. 3(2): 41-47.

Wlasow T, Kuzminski H, Woznicki P, Ziomek E. 2004. Blood cells alteration in triploid brook trout Salvelinus fontinalis (Mitchill). Acta Vet. (Brno) 73:25-29.

Woznicki P, Kuzminski H. 2002. Chromosome number and erythrocyte nuclei length in triploid brook trout (Salvelinus fontinalis). Caryologia 55:295-298. 